\title{
Evaluation of Factors Affecting Mortality Rates and Survival in Cancer Patients Followed up in the Intensive Care Unit
}

\author{
Pakize Özçiftci Yılmaz ${ }^{1 *}$, Cihangir Doğu² ${ }^{2}$ Ahmet Bindal ${ }^{3}$, Esra Yakışık Çakır ${ }^{3}$, Zeyney Nur Akçaboy and Işıl Özkoçak \\ Turan $^{3}$
}

${ }^{1}$ Aydin State Hospital, intensive Care Unit, Turkey

${ }^{2}$ Erol Olçok Education and Research Hospital, intensive Care Unit, Turkey

${ }^{3}$ Ankara Numune Training and Research Hospital, Intensive Care Clinic, Turkey

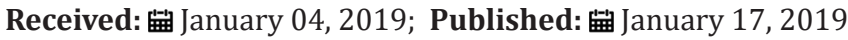

*Corresponding author: Pakize Özçiftci Yılmaz, Aydın State Hospital, intensive Care Unit, Turkey

\begin{abstract}
Objective: The aim of this study was to evaluate the factors affecting mortality in malignant patients followed up in the intensive care unit.

Materials-Methods: The demographic data, APACHE II scores, Charlson comorbidity scores (CCS), laboratory values, durations of intensive care stay and mechanical ventilation, vasopressor requirement, comorbidities developed and discharge types from intensive care of the malignant patients hospitalized in intensive care unit between March 1, 2014, and October 31, 2015, were recorded.

Results: One hundred and thirty-six patients were included in the study. The mean age was 61, the mean APACHE II score was 15, the mean CCS score was 6.8, the mean length of hospitalization was 14.9 days, and the mean duration of MV was 21 days. APACHE II score and the duration of mechanical ventilation were found to be correlated with mortality ( $p<0.001)$. Laboratory parameters of urea, creatinine elevation ( $p=0.001)$, low hemoglobin - hematocrit levels ( $p=0.005-p=0.004)$ and low prealbumin levels $(p=0.004)$ were found to be correlated with mortality.

Conclusion: Renal failure, respiratory failure, mechanical ventilator dependence and infection are independent factors correlated with mortality in malignant patients hospitalized in intensive care unit.
\end{abstract}

Keywords: Malignancy; Mortality; Intensive Care Unit

\section{Introduction}

Cancer is referred to as the definition of systemic malignant disease, which grows locally or spreads to distant organs or tissues as a result of uncontrolled proliferation of cell groups $[1,2]$. Today, cancer is the second leading cause of death following cardiovascular diseases, and lung, breast and colorectal cancers are the most common cancers worldwide [3]. The incidence rate of cancer is approximately estimated to be $85-350$ cases per 100,000 people in the whole world population, although it varies depending on cancer type, age and gender of patient and geographic region $[1,4]$. This incidence, cancer-related mortality and morbidity increase over the years [5]. Some studies on intensive care suggest that morbidity increases more especially due to ventilator-related respiratory problems associated with prolonged hospitalization and complications developing because of conditions such as leukopenia, while some studies report that intensive care units provide palliative support to cancer patients, reducing morbidity and mortality rates [6,7]. Many factors are effective on survival in patients with the diagnosis of malignancy who are followed up in intensive care unit. The aim of our study was to evaluate the factors affecting mortality rates and survival in the malignancy patients whom we followed up in our intensive care unit.

\section{Materials and Methods}

Our study was designed retrospectively, and the approval for the study was obtained from the local ethics committee of the University of Health Sciences, Ankara Numune Training and Research Hospital. The data of the cancer patients older than 18 years of age, who were followed up longer than 24 hours in the intensive care unit between March 1, 2014 and October 31, 2015, were screened. The age, gender, admission APACHE II score, length of hospitalization, 
referring department (department or emergency unit), primary malignancy, comorbidities, Charlson comorbidity score, history of chemotherapy-radiotherapy-cancer surgery in the recent month, reason for admission to intensive care unit, mechanical ventilator requirement, the duration of mechanical ventilator (MV), need for vasopressor support, admission biochemistry (liver and kidney function tests, albumin level, sodium, potassium, calcium levels) and hemogram (hemoglobin, hematocrit, white blood cell, neutrophil, platelet levels) values, need for dialysis during followup, presence of organ failure developed during follow-up (acute renal failure, cytopenia, acute liver failure, tumor lysis syndrome, respiratory failure, infection, sepsis, etc.), type of discharge from intensive care unit (discharged, transferred, exitus) of the patients meeting the inclusion criteria within the scope of the study were retrospectively screened. The indicated data were recorded by analyzing the patients' hospital and intensive care records. Patients, who were under the age of 18 years, followed up less than 24 hours and did not have cancer, were not included in the study. The data were analyzed using the SPSS statistical analysis software at the end of the study.

\section{Statistical Analysis}

The obtained data were analyzed using a statistics program (SPSS, Version 17, Chicago IL, USA). The study included the descriptive statistics for the categorical and continuous variables (mean and standard deviation, median value, minimum, maximum, number, and percentages). the Student's t-test was used when the variable met the preconditions of the parametric test, and the Mann - Whitney U-test when it did not. The Monte Carlo Simulation Method was used to include variables the frequencies of which were

\section{Results}

Table 1: Descriptive data of patients.

\begin{tabular}{|c|c|c|c|c|}
\hline & N & Mean & Minimum & Maximum \\
\hline Apache score & 136 & 15,23 & 1 & 42 \\
\hline $\begin{array}{c}\text { Hospitalization } \\
\text { time (day) }\end{array}$ & 136 & 14,93 & 2 & 115 \\
\hline $\begin{array}{c}\text { Duration of } \\
\text { malignancy (day) }\end{array}$ & 136 & 21,07 & 1 & 812 \\
\hline $\begin{array}{c}\text { Charlson } \\
\text { comorbidity score }\end{array}$ & 136 & 6,82 & 2 & 15 \\
\hline $\begin{array}{c}\text { Duration of } \\
\text { mechanical } \\
\text { ventilation (day) }\end{array}$ & 136 & 11,01 & 0 & 112 \\
\hline
\end{tabular}

The study included 136 patients; 93 (68.4\%) were male and $43(31.6 \%)$ were female. The highest number of patient admission was from the emergency department (43.4\%), followed by the hematology (12.5\%) and medical oncology clinic (8.8\%) . The patients' mean age was 61 years, mean APACHE II score was 15, mean length of hospitalization was 14.9 days, mean duration of malignancy diagnosis was 21 days, mean CCS score was 6.8 and mean duration of MV was 11 days (Table 1). Lung cancer (18.4\%), hematologic cancers (13.2\%) and gastric cancer (8.1\%) were determined to be the top three most common types of cancer. It was seen that the patients were most frequently admitted to the intensive care unit due to respiratory failure (55.1\%). Fifty-seven (41.9\%) patients were discharged, while 79 (58.1\%) patients were lost. APACHE II score and the duration of MV were found to be correlated with mortality $(\mathrm{p}<0.001)$. Laboratory parameters of urea, creatinine elevation $(p=0.001)$, low hemoglobin - hematocrit levels $(\mathrm{p}=0.005-\mathrm{p}=0.004)$ and low prealbumin levels $(\mathrm{p}=0.004)$ were found to be correlated with mortality. There was no statistically significant correlation between other parameters and mortality.

\section{Discussion}

Cancer is a very important group of diseases in which early diagnosis is essential and treatment and diagnosis of which require the cooperation of many specialties. Local treatment modalities such as surgery and radiotherapy, and systemic treatments such as chemotherapy and immunotherapy are administered [8]. Cancer patients is a group of patients with a higher rate of intensive care unit and hospital mortality compared to patients without cancer. In recent years, numerous studies were conducted on the factors affecting the mortality of malignant patients hospitalized in intensive care unit [9]. Patient's performance, hematological malignancy, bone marrow transplantation, presence of organ failure or infection, MV or vasopressor support requirement and low partial pressure of oxygen/fraction of inspired oxygen ( $\mathrm{PaO} 2 /$ FiO2) ratio were found to be correlated with increased mortality $[9,10]$. Cosgrove et al. [11] reported that high APACHE II score adversely affected mortality, whereas Toffart et al. [12] reported that the duration of receiving mechanical ventilator support adversely affected mortality.

Likewise, APACHE II score and the duration of mechanical ventilator were found to be correlated with mortality in our study $(\mathrm{p}<0.001)$. Again, in parallel with the literature, the mortality rate was found as $73.3 \%$ in the patients followed up in intensive care unit due to hematological malignancy. Considering various studies in the literature, it can be said that the reasons for admission of malignant patients to intensive care unit are different. Kres et al. [13] reported that respiratory failure was the most common cause of admission to intensive care unit, while sepsis, renal failure and cardiac problems came to the forefront in some studies [14]. In our study, the most common cause of hospitalization was also respiratory insufficiency, followed by general condition disorder and impaired consciousness. Ursavas et al. [15] emphasized that respiratory failure was a very important factor associated with mortality, and reported the factors affecting mortality as hospitalacquired infection, renal failure, malignancy and mechanical ventilation dependence. When the laboratory data of the patients were evaluated in our study, it was observed that urea and creatinine elevation and prealbumin, an acute phase reactant, were statistically significant in terms of mortality.

As with other studies in the literature, we are of the opinion that renal failure and infections have a negative effect on mortality. One of the undesirable but frequent complications of cancer treatment is neutropenia [16]. Since most of intensive care admissions are due to neutropenic fever, we think that intensive care management of this group of patients should be carried out well. In their 
study, Saillarad et al. [17] reported that neutropenia was a factor significantly increasing the mortality in intensive care unit, therefore recommended that broad-spectrum, antipseudomonal antibiotic therapy be initiated immediately to avoid sepsis and septic shock. Unlike literature, we did not find statistical significance between neutropenia and mortality in our study. We think this is due to the number of patients included in the study. In conclusion, as reported by many multicentre studies, numerous reasons, such as organ failure and number, being connected to invasive mechanical ventilation, presence of infection, vasopressor requirement, patient's performance, history of previous chemotherapy and presence of neutropenia, renal dysfunction, play an important role in the mortality of malignant patients hospitalized in intensive care units. In our study, we have also corroborated these with similar results. More attention to these factors in patients requiring followup in intensive care unit for malignancy reasons will result in lower mortality rate.

\section{References}

1. Aksoy Y, Kaydu A, Sahin OF, Kaçar CK (2016) Analysis of cancer patients admitted to intensive care unit. North Clin Istanb 3(3): 217-221.

2. Homburger F, Hayes JA, Pelica W (1983) A guideto general toxicology. Karger continu ingedukation series. Basel, Switzerland, 1983: pp. 199.

3. Bray F, Ren JS, Masuyer E, Ferlay J (2013) Estimates of global cancer prevalence for 27 sites in the adult population in 2008. Int J Cancer 132(5):1133-45.

4. Parkin DM, Bray F, Ferlay J, Pisani P (2005) Global cancer statistics, 2002. CA Cancer J Clin 55(2):74-108.

5. Eaton L (2003) World cancerrates set to doubleby 2020. BMJ 326(7392): 728.

ISSN: 2574-1241

DOI: 10.26717/BJSTR.2019.13.002368

Pakize Özçiftci Yılmaz. Biomed J Sci \& Tech Res

cC) (i) This work is licensed under Creative

Submission Link: https://biomedres.us/submit-manuscript.php
6. Regazzoni CJ, Irrazabal C, Luna CM, Poderoso JJ. [2004] Cancer patients with septic shock: mortality predictors and neutropenia. Support Care Cancer 12(2): 833-839.

7. Azoulay E, Afessa B (2006) The intensive care support of patients with malignancy: do everything that can be done. Intensive Care Med 32: 3-5.

8. Berkarda B (1998) Medikal Onkolojiye Giriş Hatemi, Hüsrev. Medikal Onkoloji. In: Firm H (Eds.). Yüce Yayınevi p. 9-22.

9. Kılıç G (2015) Yoğun Bakımda Takip edilen Malignite Hastalarının Süreçlerinin Değerlendirilmesi, Uzmanlık Tezis p. 49-50.

10. Song JU, Suh G, Park H, Lim S, Han S, et al. (2012) Early intervention on the outcomes in critically ill cancer patients admitted to intensive care units. Intensive Care Medicine 38(9): 1505-1513.

11. Cosgrove J, Nesbitt I, Bartley C (2006) Futility and the critically ill adult patient: A framework. Current Anaesthesia \& Critical Care17(5): 255262.

12. Toffart AC, Timsit JF (2013) Is prolonged mechanical ventilation of cancer patients futile? Critical Care 17(5): 189.

13. Kress JP, Christenson J, Pohlman AS, Linkin DR, Hall JB (1999) Outcomes of critically ill cancer patients in a university hospital setting. American Journal of Respiratory and Critical Care Medicine 160 (6): 1957-1961.

14. Soares M, Salluh JI, Torres VB, Leal JV, Spector N (2008) Short and longterm outcomes of critically ill patients with cancer and prolonged ICU length of stay. Chest 134(3): 520-526.

15. Ursavaș A, Ege E, Yüksel EG, Atabey M, Coşkun F, et al. [2006] Solunumsal Yoğun Bakım Ünitesinde Mortaliteyi Etkileyen Faktörler.Yoğun Bakım Dergisi 6(1): 43-48.

16. Vioral AN, Wentley D (2015) Managing oncology neutropenia and sepsis in the intensive care unit.Crit Care Nurs Q 38(2): 165-174.

17. Saillard C, Sannini A, Chow Chine L, Blache JL, Brun JP, et al. (2015) Febrile neutropenia in onco-hematology patients hospitalized in Intensive Care. Unit Bull Cancer 102(4): 349-359.

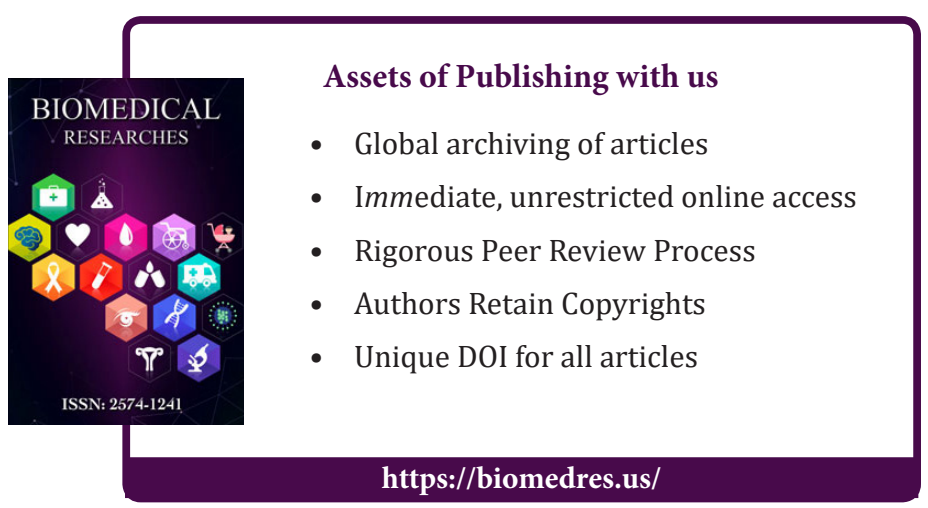

